PACE Policy Research Paper:

Civil Service Reforms in Pakistan

Paper presented at the $34^{\text {th }}$ Annual Conference of Pakistan Society of Development Economics (PSDE) - December 12 - 14, 2018, Islamabad, Pakistan

\title{
April 2019
}

Authored by:

Abdul Wajid Rana

Program Leader

Pakistan Agricultural capacity Enhancement Program (PACE)

International food Policy Research Institute - Pakistan (IFPRI) 


\section{Table of Contents}

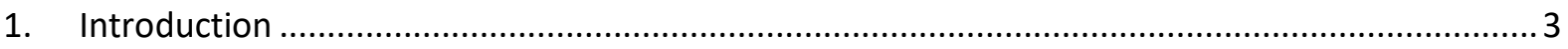

2. Efforts to Reform Governance and Civil Service in Pakistan ................................................. 6

3. Redefining the Role of the State and Political Needs Assessment ............................................. 7

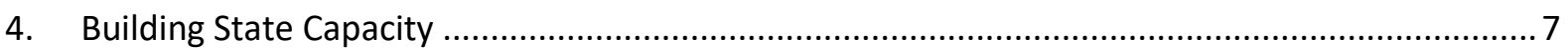

5. Inter-dependence of Politics, Policy, and Administration ...................................................... 8

6. Size of the Government and Organizational Structures ......................................................... 9

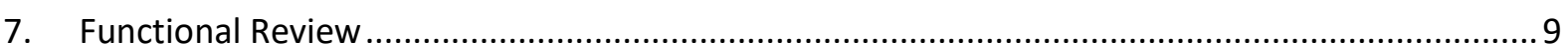

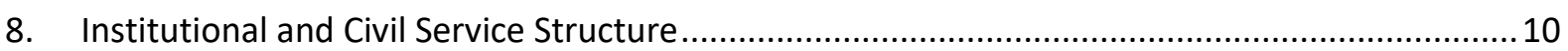

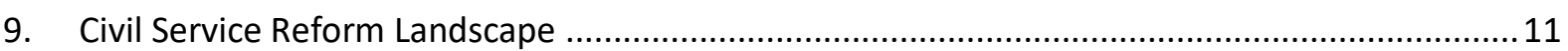

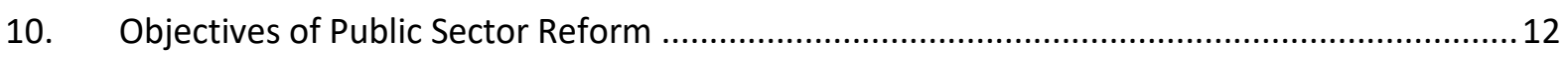

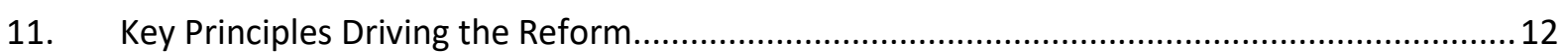

11.1 Approaches to Civil Service Reform and Choice Decisions ................................................. 13

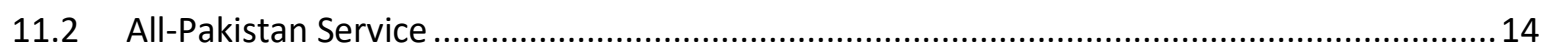

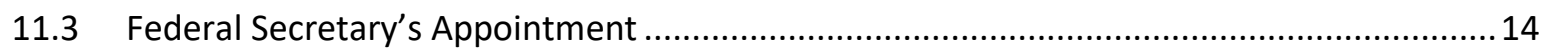

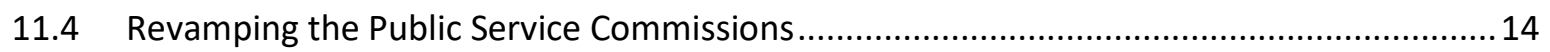

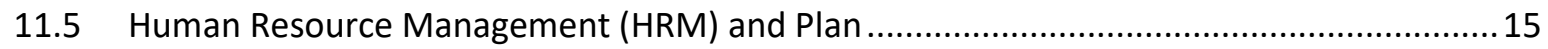

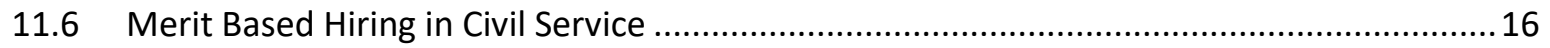

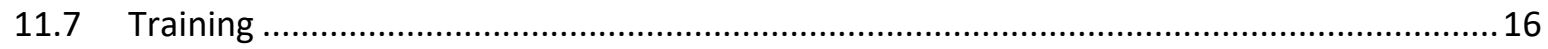

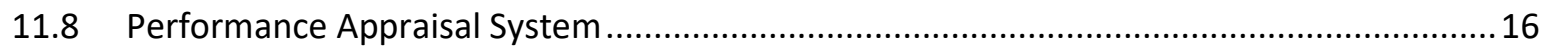

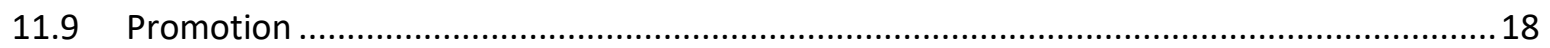

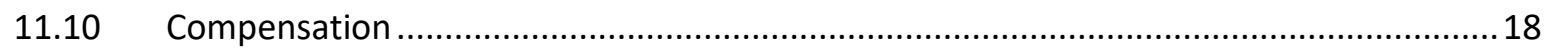

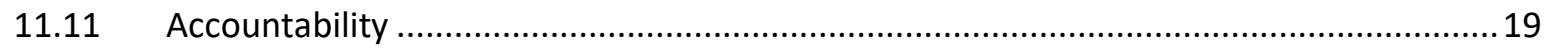

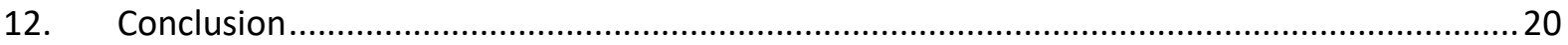




\title{
Civil Service Reforms in Pakistan
}

\author{
Abdul Wajid Rana ${ }^{1}$
}

\begin{abstract}
"When an empire begins to enter into a stage of decline, often the bureaucracy becomes corrupt. The ruler becomes increasingly despotic, arrogant, and less just. This leads to a centralization of power and increased nepotism and corruption. Once formal procedures are regularly ignored, this represents the beginning of the end."-Ibn Khaldun
\end{abstract}

\section{Introduction}

Effective governance is one of the key challenges for both developing and developed countries. Governments, today, are increasingly encountering complex and cross-cutting issues such as economic and financial volatility, internal and external conflicts, growing social tensions, adverse demographic trends, climate change vulnerabilities, weak regulatory regimes, huge infrastructure and service delivery gaps, state and elite capturing and sustaining rule of law. Faced with growing criticism of infectiveness of state institutions undermining country's economic, social and political development because of weakening capacity of public officials to pace up with emerging challenges, there is a renewed interest in reforming the governance and reforming the civil service.

Figure 1. Governance Indicators-2018 ${ }^{2}$

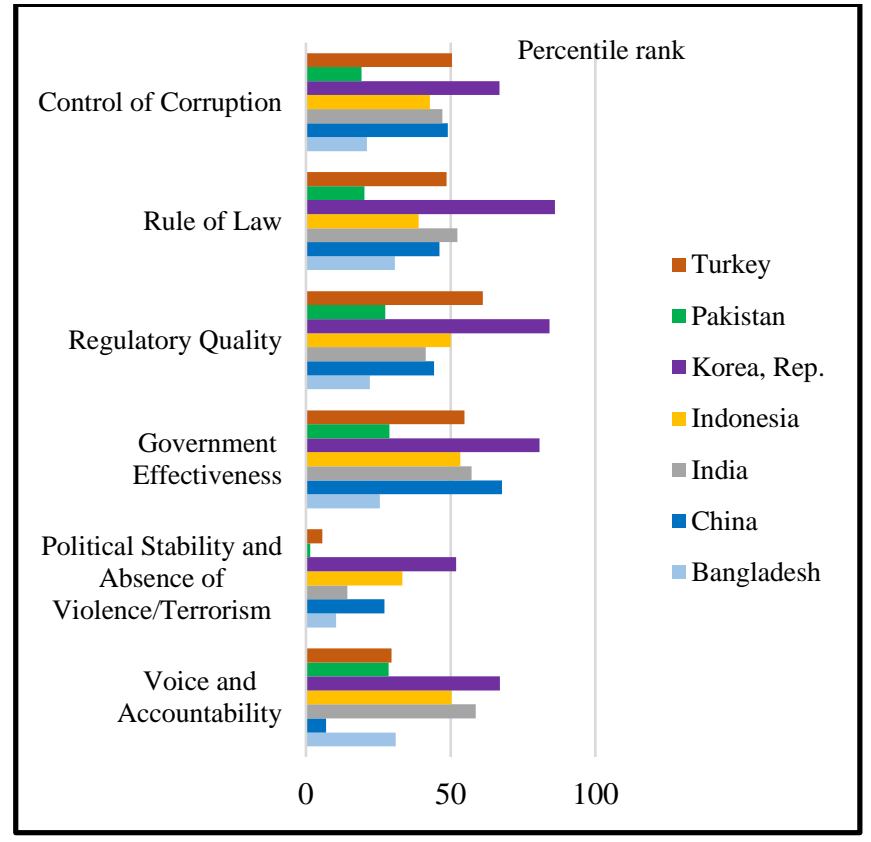

Key challenges Pakistan has been enduring for more than five decades include: (i) security and regional geopolitics; (ii) political economy factors including civil-military relationship; (iii) weak policy formulation process; (iv) declining quality of public administration system; (v) poorly designed and hastily implemented devolution and fiscal decentralization (2001 and 2010); (vi) dominance of state in the market; (vii) weak economic governance with brief periods of stability; and (viii) entrenchment of vested interests and

\footnotetext{
${ }^{1}$ The Author is retired Federal Secretary Finance and Member, Federal Public Service Commission

${ }^{2}$ World Bank Group Governance Indicators 2018
} 
elite capturing. Ensuring political settlements for short-term patronage-based gains, far too long, have undermined effectiveness of the state. Today, Pakistan ranks in the lowest percentile in most governance indicators (see Figure 1). Concomitantly, public policy and governance dynamics have undergone major restructuring post- $18^{\text {th }}$ Constitutional Amendment in 2010, transforming Pakistan from a layered-cake hierarchical dual federalism to collaborative federalism leading to collaborative and participative governance. Article 90 and 129 of the Constitution, as amended in 2010, have added new complexities to both public policy formulation and public administration at federal and provincial levels. ${ }^{3}$

Globalization and advances in communication technology has incited additional challenges. Efforts to dismantle the excessive state under the influence of "Washington Consensus" aiming at removing distortions and fiscal consolidation ${ }^{4}$ followed by liberalization, privatization, deregulation in 1990s and 2000s and rapid technological advancement required different set of skills, expertise, values, attitude and knowledge in public officials. The ubiquitous use of internet and social media has raised the level of expectations in terms of speed, quality and personalization of public service delivery. With a more educated as well as vocal citizenry savvy in the use of social media, an effervescent and highly vigilant media, vibrant judiciary, active Legislative Committees and political agenda for change and transformation, public servants are finding themselves under ever keener and intense public scrutiny and expectations.

Today, there is a broad agreement among policy makers throughout the world that a lean, efficient and professional civil service is a necessary, though not sufficient, requirement for an effective governance in any country. The governments around the world are pushing the ideas of "hallow state"5, "lean, efficient and facilitative government", "paperless government", "practical government" and decentralization. To coup up with the challenges of $21^{\text {st }}$ century, many countries have reformed their civil service system, such as UK, Canada, Australia, South Africa, Brazil, and many countries are on the path of reforming the system to ensure professionalism and efficiency of public administration. Some countries have adopted the concept of "incorporation" to foster close public-private sector collaboration and transforming the civil service that promotes competitiveness of the private sector. To the contrary, Pakistan remained a straggler despite establishment of National Commission for Government Reforms in 2006 and huge investment of time and resources for securing a pragmatic as well as implementable governance reform plan. In the interregnum, size of the national and sub-

\footnotetext{
${ }^{3}$ Article 90 before the $18^{\text {th }}$ Amendment stipulated that "The executive authority of the Federation shall vest in the President and shall be exercised by him, either directly or through officers subordinate to him, in accordance with the Constitution. $18^{\text {th }}$ Amendment changed this position to: "(1) Subject to the Constitution, the executive authority of the Federation shall be exercised in the name of the President by the Federal Government, consisting of the Prime Minister and the Federal Ministers, which shall act through the Prime Minister, who shall be the chief executive of the Federation. (2) In the performance of his functions under the Constitution, the Prime Minister may act either directly or through the Federal Ministers."

${ }^{4}$ Nadeem-ul-Haq, "Why Civil Service Reforms do not Work”, SSRN Electronic Journal, February 2007.

${ }^{5}$ Hallow State where government reduces its role as a direct supplier of public goods by contracting public service delivery out to private organizations.
} 
national governments in Pakistan kept swelling, especially at the lower end of bureaucracy, colonial laws, rules and procedures continued weakening critical areas of governance further, and political polarization and wide-ranging bashing of the bureaucracy triggered impasses and inertia. This paper will take stock of reform efforts since 1947, contemporary approaches for public sector reform, and addressing key elements of civil service reform (CSR).

There is a growing recognition that CSR is a continuous process with no general starting point, and equally no end. Civil Services reform cannot be seen in isolation and it must be undertaken along with political governance and inclusive reforms for effective results. Political governance reform needs to focus on eliminating culture of neo-patrimonialism and politics of kinship and patronage which frustrate any move towards modernism. Any effort for CSR will fail to bring a meaningful change in an environment where state institutions and political governance constantly broker their authority for the reasons:

(i) power imbalance between the very strong, rigid, and over-centralized bureaucratic institutions and weak democratic institutions;

(ii) challenges hurled to popular sovereignty by non-state actors undertaking many of state functions;

(iii) institutionalization of elaborate system of patronage and clientele making the civil bureaucracy dysfunctional;

(iv) bloating federal government despite devolution under $18^{\text {th }}$ Constitutional amendment;

(v) closed structure of the civil service;

(vi) ever expanding employment at low-skills levels with uneven management structure, particularly at sub-national level;

(vii) an inappropriate skill-mix and archaic training structure;

(viii) fragile inter-Ministerial harmonization;

(ix) colonial laws, rules and procedures that restrict innovation, knowledge and agile concepts;

(x) elite-capturing and endemic rent-seeking making the institutions irrelevant;

(xi) ineffective incentive system that rewards the incompetent;

(xii) political interference and administrative acquiescence leading to systemic inconsistencies and arbitrariness in decision-making;

(xiii) lack of transparency and weak internal accountability;

(xiv) increasing public sector wage costs crowding out operational expenditures;

(xv) politically oriented bulge in development expenditure squeezing the recurrent budget further; and 
(xvi) resistance to change and reform.

\section{Efforts to Reform Governance and Civil Service in Pakistan}

The Government has constituted around 40 Commissions and Committees since 1947 to reorganize and reform the civil service prior to recently constituted Task Force on Institutional Reform and Austerity and Civil Service Reform, most with flawed composition, and imperfect Terms of Reference. Generally, the proposed reforms with some exception were loosely structured and its primary focus had always been the higher civil service (the Central Superior Services), particularly one cadre, without addressing the issues relating to federal and provincial government structures and lower levels, which is 95 percent of the bureaucracy. Induction of private sector as well as "expatriate" favourites at disproportionate compensation under the garb of creating a healthy mix of skill-set not only demoralizes the bureaucracy but at times, making the institutions dysfunctional. Most Commissions and Task Forces considered civil service reform a technical exercise--where problems are reduced to boxes and then solutions are found to fit into the boxes instead of aligning them to pre-determined politically owned objectives and goals. Due to absence of precision in objectives and goals, general direction, a realistic assessment of political as well as cultural contexts, an analysis of existing operating environment and rustic processes and procedures, the effectiveness of these exercises is lost after initial steam.

The deliberations during these meetings generally remains perception based or anecdotal rather than an evidence-based analysis. The recommendations are largely motivated by short-term priorities as well as political compromises instead of addressing key issues facing the civil service including compensation that has led to consistent decline in Pakistan's ranking in Government effectiveness (see Figure 2). For these reasons, quite often the reports

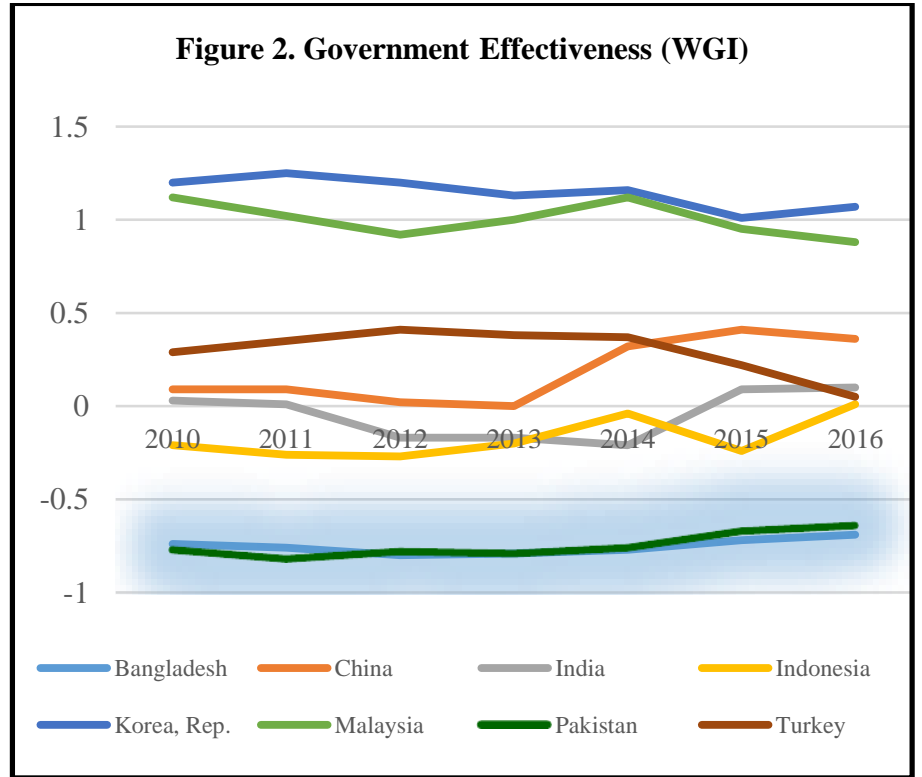
of these Commissions/Committees Commissions/Committees were either not made public or shelved without seeking formal approval or implementation. ${ }^{6}$ Those implemented, ended up fragmenting the public sector and civil service further rather than bringing any qualitative improvement in governance. The present exercise is no different.

\footnotetext{
${ }^{6}$ Report of National Commission for Government Reforms
} 
Aspirations for good governance will not succeed if the requisite conditions for good governance are not there. Reforms should not only focus on clearly defined objectives and goals to be accomplished but also on creating conditions necessary to sustain effective governance. It mandates reforming all areas of governance including economic policies which lead to inclusive growth and greater equality, civil service and public administration, corporate governance, regulatory bodies and service delivery, and governance institutions: political, executive, legal and legislative for establishing a transparent and accountable system. Similarly, the objective of good governance may not be realized in a political system which is too weak and vulnerable to frequent gridlocks. Strong system of checks and balances helps in circumventing state capture by interest groups as there are ample incentives in a country to subvert good governance resulting in efforts at rent-seeking and state capture. Strengthening institutions (executive, political, judicial, and markets) could fortify trust in the state, create opportunities for citizen participation, better access to service delivery, and increased investment, foreign and domestic, increase the role of the private sector and alleviate the Government's burden.

\section{Redefining the Role of the State and Political Needs Assessment}

The state has been a dominant player in Pakistan since 1960s playing a considerable role ranging from national security and economic development to all areas of service delivery that expanded the public sector disproportionately with weakening institutions germinating the state-capturing. Synchronously, the private sector has continuously relied on subsidies, concessions, and rent-seeking. Therefore, the starting point for designing reform package is to redefine the role of the state and an objective assessment of current political needs, capability and effectiveness of the state ${ }^{7}$ from where must flow institutional and civil service reforms rather than isolated arbitrary decisions. Secondly, the Task Force must recognize that both the governments and the markets are institutions that interact continuously for nibbling their niches and resource allocation, thus, the rules governing the institution are critical, particularly the rules determining how decisions are made within it and how these are aggregated as institutions consist of multiple individuals with differences in preferences and beliefs. ${ }^{8}$

\section{Building State Capacity}

State must define precise goals and policies that it intends to pursue. Building state capacity implies the ability to formulate and implement policy, enforce legislation and deliver services

\footnotetext{
${ }^{7}$ Capability, as applied to states, is the ability to undertake and promote collective actions efficiently such as law and order, public health, and basic infrastructure; effectiveness is a result of using that capability to meet society's demand for those goods. Therefore, the state must focus, first, what capability it has on those tasks to undertake and then focus on building additional capability. Likewise, the pathway to greater effectiveness leads, first to focusing on fundamental tasks and leveraging the state's limited capability through partnerships with the business community and civil society (World Development Report, 1997).
}

${ }^{8}$ Joseph E. Stiglitz, "Markets, States And Institutions”, Roosevelt Institute Working Paper, June 2017. 
(Barkey and Parikh, 1991; Vom Hau, 2012:4, Fukuyama, 2013: 4). It assumes the essential capacities that the state requires in development realm are: (a) bureaucratic capacity to manage resources, implement policy and laws; (b) legal capacity to enforce contracts, property rights and other legal regime effectively and speedily; (c) territorial capacity to employ all elements of national power to defend its territorial boundaries; (d) fiscal capacity to extract tax revenues from society and its diligent management; (e) infrastructural capacity to shape societal behaviour and service delivery; and (f) coercive capacity to deter or repel challenges to internal or external security. ${ }^{9}$

Generally, the state capacity is considered synonymous to bureaucratic capacity based on two key components: effectiveness-the ability to successfully implement policies; and accountability-the ability to ensure that public policy is not subverted by private incentives. These two components generate four dimensions of the bureaucratic capacity that a state needs to focus: (i) rationality that represents the rational, technical, hierarchical or hybrid organizations of administrative control (Fukuyama, 2011); (ii) restraint which is the disciplinary enforcement of formal, impersonal, and rule-bound conduct in administrative action (Weber, 1978; Yanguas, 2012); (iii) embeddedness that encompasses the interactive ties and channels of communication between bureaucratic actors and stakeholders and recipients (Vom Hau, 2012); and (iv) autonomy which represents the independent implementation of public policy without succumbing to informal pressures originating from regime actors and societal groups (Fukuyama, 2013; Vom Hau, 2012). ${ }^{10}$

\section{Inter-dependence of Politics, Policy, and Administration}

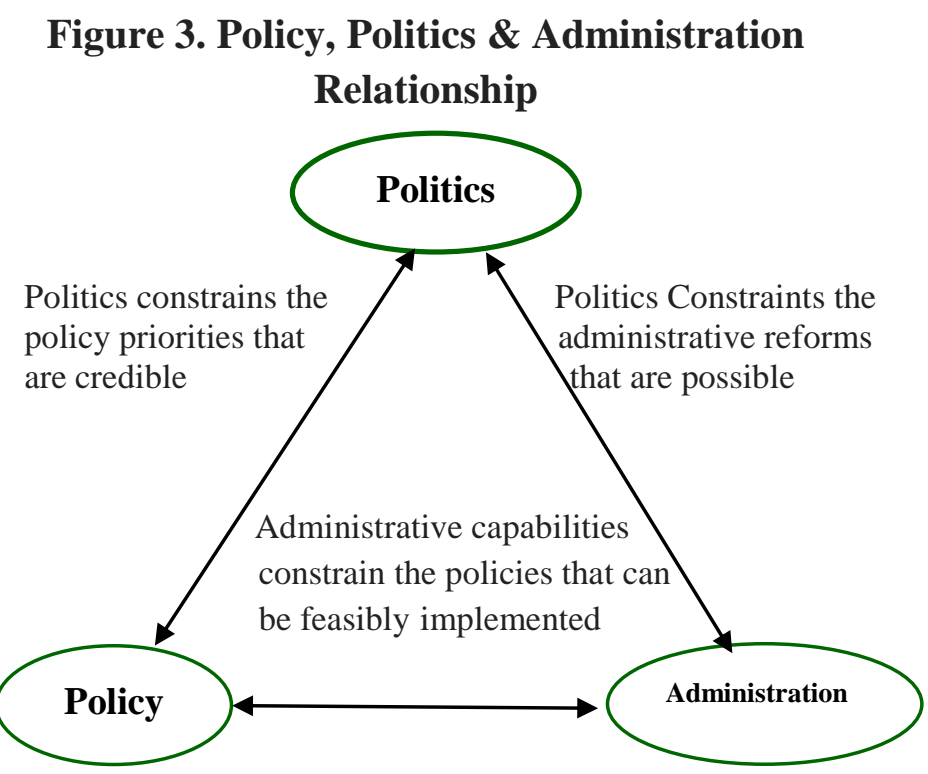

Quite often these Commissions/ Task Forces also failed to appreciate the relationship between politics, policy and public administration which is in turn influenced by country's geopolitical position, stage of development, its natural resources endowment, political environment, and human capital. Figure 3 vividly demonstrates that administrative and governance priorities are to a large extent

\footnotetext{
${ }^{9}$ Badru Bukenya and Pablo Yanguas, "Building State Capacity for Inclusive Development: The Politics of Public Sector Reform", Working Paper No. 25, Effective States and Inclusive Development Research Centre (ESID), The University of Manchester, UK.

${ }^{10}$ Ibid.
} 
dependant on the policy priorities of a country and other endowments including human capital. In the end, political dynamics and politics determine the support for acceptable policies.

\section{Size of the Government and Organizational Structures}

Redefining role of the state leads to reassigning functions between private and public sectors that determines latter's size, organizational structures (hierarchical, flat or hybrid), decisionmaking tiers and the skills that are required to perform assigned functions. This necessitates a comprehensive functional review of each level of government as well as Ministry/department. Functional review may be backed up with reduction in decision-making tiers from 5 (Section Officer to Secretary) to 4 (Assistant Secretary, Under Secretary, Joint Secretary, and Secretary) and from 4 to 3 in provincial governments which is expected to accelerate decision-making. It must be combined with major restructuring of the support staff introducing common pool sharing concept.

\section{Functional Review}

Governments perform various functions which can be categorized as: (i) policy functions including strategic planning, legal drafting, resource management, development of performance contracts, minimum standards, norms, policy analysis and evaluation, forecasting; (ii) service delivery functions such as the provision of products or services to internal (other public authorities) or external (people, civil society organization, children) customers; (iii) regulatory functions e.g. licensing, certification, permissions, accreditation, inspection, compliance, and financial audit; (iv) coordination, supervision and performance monitoring functions which includes coordinating relationship

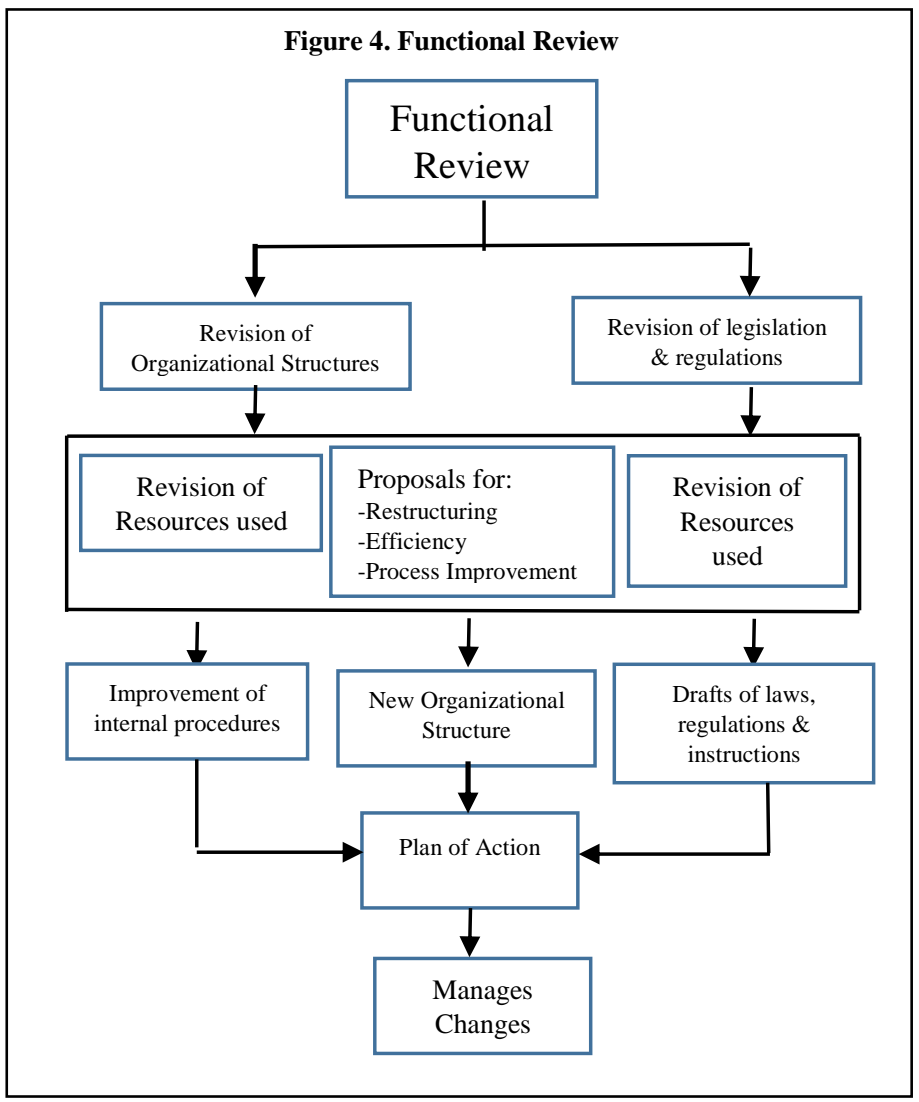
between different bodies, monitoring the performance of relationships between different bodies, monitoring the performance of subsidiary bodies, facilitating and enabling subsidiary bodies to reach their performance targets; and (v) ssupport functions: financial management, 
human resources management, information systems, infrastructure, staff training, efficiency review, and management audit as well as secretarial services.

Functional review requires litmus test of each function through the prism of KATRRD, i.e. keep the function without change, abolish the function, transfer the function to another public organization, or to an executive department, or to private enterprise, or to non-government organization, rationalize the function, reduce certain aspects of the function performance, or decentralize the function. The Task Force must have clarity as to objectives it intends to accomplish and correspondingly choose one or a combination of the approaches for functional review: (i) pure policy or program reviews reprioritizing policy or programs and eliminating the low-priority program; (ii) pure efficiency reviews focusing on identifying organizational and business process changes for greater efficiency; (iii) upstream program and efficiency review focusing on large-scale restructuring; (iv) mainstream ministry/agency-level functional review focusing on elimination of duplication, consolidation of similar services and merger of similar functions from different ministries/ agencies (v) downstream organizational reviews and business process re-engineering entailing restructure functions and activities within same ministry, automation and contracting out some functions. ${ }^{11}$ The design of functional review is at Figure 4. ${ }^{12}$

\section{Institutional and Civil Service Structure}

Figure 5. Structure of Civil Service

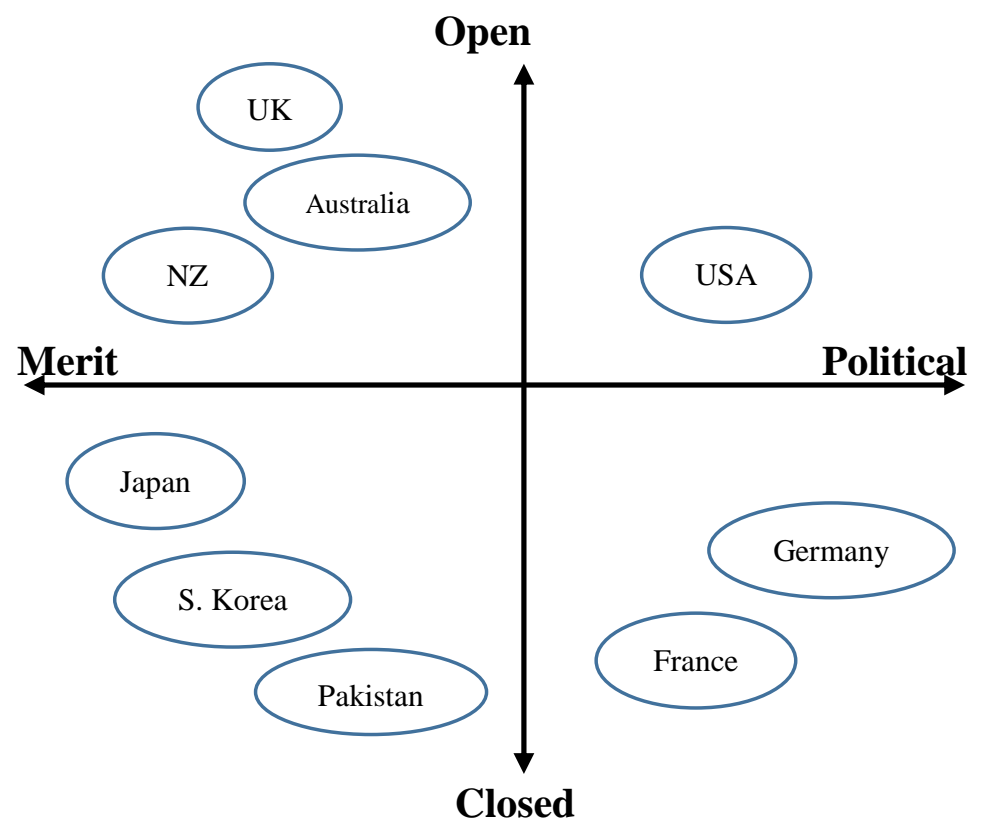

Functional reassignment and institutional restructuring through functional review at the federal, subnational and market levels will provide a fair assessment of manpower as well as skills-set needed which will logically lead to required civil service reform and human resource hiring. However, before reforms in this area are considered, a government needs to choose between centralized or decentralized civil service system. In case of latter, five levels of civil service must be considered to perform assigned functions including inter-governmental, federal, provincial, Local or district civil service and

\footnotetext{
${ }^{11}$ Nick Manning and Neil Parison, "Determining the Structure and Functions of Government Program and Functional Reviews", The World Bank, Moscow, October 2004

12 Olga Lukashenko, Vladimir Vlajković, and Jasna Stojanović, Towards Effective Public Administration: Methodology For Functional Analysis, 2009
} 
Agency service system. It will be followed by a decision

about choice of

civil service structure from amongst (a) merit based open system; (b) merit based closed system; (c) political open system; and (d) political closed system; or a combination of these systems (see Figure 5).

\section{Civil Service Reform Landscape}

Clearly, Civil Service Reform is not merely about recruitment and training but involves deliberate changes to the structures and processes of public sector organizations with the purpose of good governance not only in political realm but also economic, legislative, judicial and humans' governance. The literature defines the civil service as "a political institution that promotes joint action among many actors and stakeholders whose effort must be bent toward the goals of public policy... an institution of governance" (McGregor, 1996). It may be added that the dimensions of collaboration that the civil service had to deal with have multiplied in the $21^{\text {st }}$ century, especially post $18^{\text {th }}$ Constitutional Amendment. The broad categories of collaborations now include: (i) between political institution and civil servants; (ii) between judiciary and civil servants; (iii) between the public and private sector; (iv) between key societal actors including politicians, academic institutions, the media, interest groups, gender and civil society; (v) national government and sub-national governments; and (vi) national government and international community.

Figure 6. Civil Service Reform Landscape

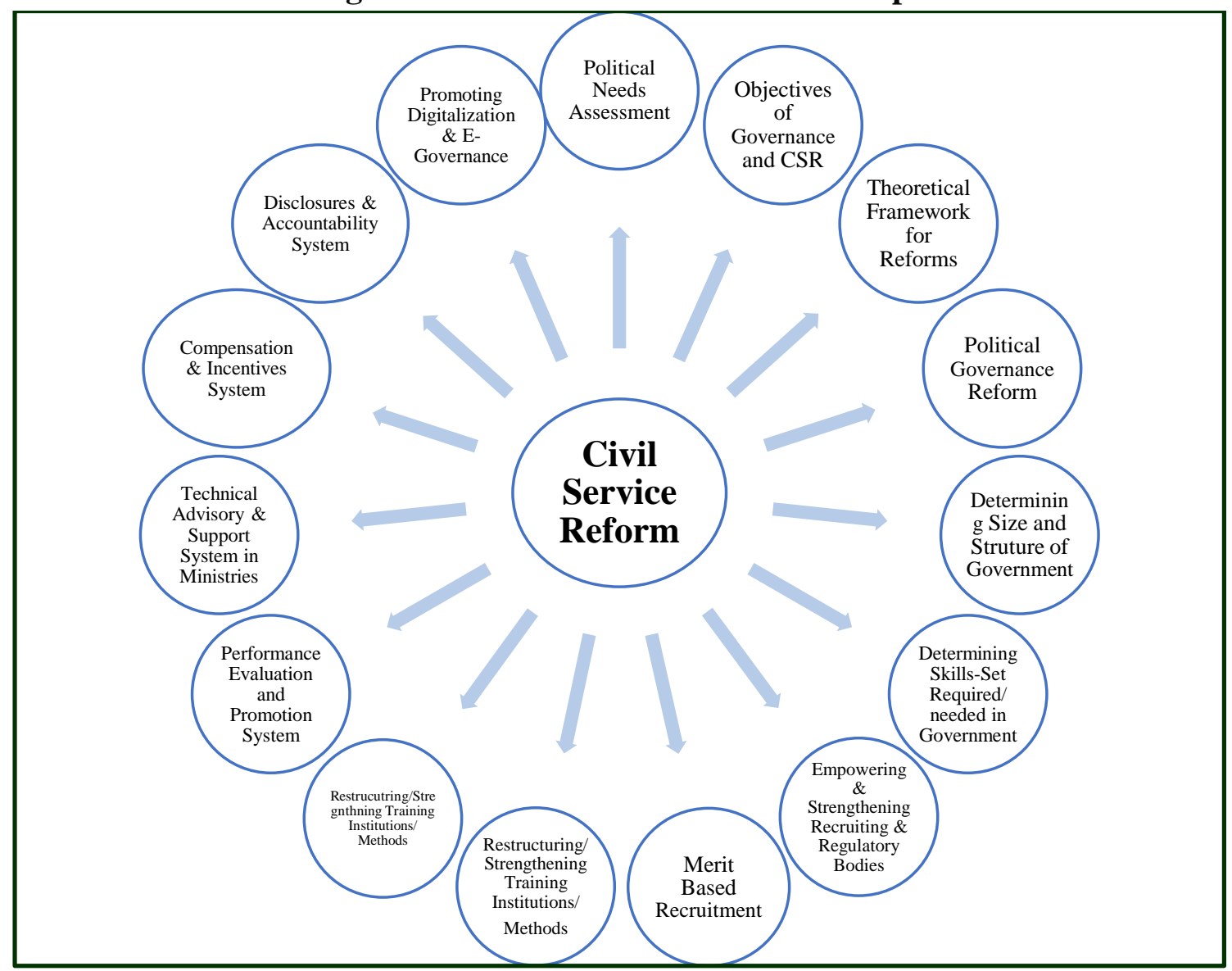


It must be recognized that the CSR is not an end by itself but means to an end. Pollitt and Geert Bouckaert have identified four ends: (i) effective policy formulation; (ii) making government operations more efficient; (iii) improving service quality and delivery and (iv) making savings in public expenditure. They have also identified intermediate ends: (i) depoliticization of the bureaucracy; (ii) enhancing the government's accountability to the legislature and citizenry for its policies, programs and financial management; (iii) freeing public officials from bureaucratic restraints that inhibit their opportunities to manage. These ends ultimately create conditions for good governance and effective government. It needs professionalism tempered with human consideration, empowerment grounded in self-discipline and commitment graced with creativity and innovation. Figure $\mathbf{6}$ describes the process for formulating civil service reform in the country.

\section{Objectives of Public Sector Reform}

Therefore, fourth generation public sector reforms for building an effective, transparent and accountable state of Pakistan must aim at: (i) establishing a professional, politically insulated, fully empowered and constitutionally mandated independent Public Service Commissions at federal and provincial levels with all appointments of Chairman and Members on the recommendations of a High Powered Selection Board; (ii) creating an inter-governmental, federal, provincial, local/district and agency civil services; (iii) creating a merit-based, politically neutral, well structured, right sized, well trained, high performing and affordable civil service at national and sub-national levels selected through competitive contemporary induction system and managed in an efficient, non-discretionary, and transparent manner; (iv) performance based annual appraisal system linked with tenured postings; (v) establishing a well-articulated and non-discretionary promotion system linked with achievements at each level; (vi) creating an effective and speedy system of internal accountability; (vii) strong and IT based public financial management system and allocation of resources fully aligned with policy priorities; (viii) establishing an equitable, efficient and accountable tax service for improved revenue performance; (ix) efficient and accountable service delivery through publicprivate partnership or outsourcing with full recovery of user charges; and (x) effective judiciary as well as accountability and transparency in the management of resources to discourage the use of public office for state capture and private gains.

\section{Key Principles Driving the Reform}

The guiding principles driving the public sector and civil service reform in $21^{\text {st }}$ Century, once the objectives are clearly defined, include: (i) a pragmatic and result oriented framework measuring productivity of the organization as well as civil service; (ii) awareness of objectives and administrative structures; (iii) political strategies and engagement with stakeholders; (iv) selecting goal-oriented competencies and skills development; (v) innovations for public service delivery; (vi) professionalisation ${ }^{13}$, motivation and moral boosting in civil service; (vii) code

\footnotetext{
${ }^{13}$ According to Free Encyclopedia, western nations use the term professional to describe a highly educated, mostly-paid, workers who enjoy considerable work autonomy and a comfortable salary and are commonly engaged in creative and
} 
of conduct for public sector ethics; and (viii) effective and pragmatic anti-corruption strategies. ${ }^{14}$ It is proposed that the federal government's human capital system be shaped by: collaboration and not authority-driven, agility and not hostage to fixed ideas; outcome-driven, and not process driven, variegated, not monolithic, and apolitical, not parties. Points to consider are:

\subsection{Approaches to Civil Service Reform and Choice Decisions}

Before a government embarks upon civil service reforms, a decision is needed regarding the approach it intends to pursue for the reforms. It can choose amongst: (a) a business-oriented approach to government or a quality and performance-oriented approach; (b) emphasis on functional responsiveness and public service delivery; (c) retreat of government institutions in favor of commercial market enterprises (deregulation, privatization and marketisation). A comparison between tradition and contemporary approach and paradigm shift in various roles (see Table 1).

Table 1. Approaches to Civil Service Reform

\begin{tabular}{|c|c|c|}
\hline Intended Purpose & Traditional & Contemporary \\
\hline Level of change & Incremental & Extensive and Comprehensive \\
\hline Service Career & $\begin{array}{l}\text { Permanency and life-long } \\
\text { employment }\end{array}$ & $\begin{array}{l}\text {-Continuing employment } \\
\text {-Contracts }\end{array}$ \\
\hline Culture & Maintaining administrative state & $\begin{array}{l}\text { Management for business efficiency } \\
\text { and markets }\end{array}$ \\
\hline Civil Service System & $\begin{array}{l}\text { Collective and Coherent } \\
\text { - Centralized } \\
\text { - Closed and bounded }\end{array}$ & $\begin{array}{l}\text { Disaggregated Units } \\
\text { - Decentralized } \\
\text { - Open and Permeable }\end{array}$ \\
\hline $\begin{array}{l}\text { Relationship with } \\
\text { politicians }\end{array}$ & $\begin{array}{l}\text { Separate and formally } \\
\text { independent }\end{array}$ & Responsive and vulnerable \\
\hline Role of civil servant & Follower and implementer & $\begin{array}{l}\text { Source of expertise and institutional } \\
\text { memory }\end{array}$ \\
\hline $\begin{array}{l}\text { Recruitment of civil } \\
\text { servants }\end{array}$ & Aptitude and skills & $\begin{array}{l}\text { Service value orientation and } \\
\text { integrity of character }\end{array}$ \\
\hline Roel of senior management & Administrative managers & Visionaries/Technocrats/Experts \\
\hline $\begin{array}{l}\text { Appointment and } \\
\text { promotion to senior } \\
\text { management }\end{array}$ & $\begin{array}{l}\text { Bias for managerial skills and } \\
\text { annual performance reports }\end{array}$ & $\begin{array}{l}\text { Competitive process/ insulated from } \\
\text { politics; major consideration are: } \\
\text { competence } \\
\text { managerial and } \\
\text { and potentials; }\end{array}$ \\
\hline Management style & $\begin{array}{l}\text { Subservience hierarchy/ } \\
\text { authority }\end{array}$ & Participatory and consultative \\
\hline $\begin{array}{l}\text { Operating perspective of } \\
\text { the Government }\end{array}$ & Regulation & Assistance and public service \\
\hline
\end{tabular}

intellectual challenging work while Friedson (1994) suggested that upper tier of the primary labour market is characterized as professional because of the lifetime, relatively secure, and stable work careers in particular identifiable processions. He placed the public servants in the upper tier.

${ }^{14}$ Joan Nwasike and Dunstan Maina (eds.), Key Principles for Public Sector Reforms, The Commonwealth, 2018. 


\begin{tabular}{|l|l|l|}
\hline $\begin{array}{l}\text { Civil service relationship } \\
\text { with other branches of } \\
\text { government }\end{array}$ & An adjunct of other branches & $\begin{array}{l}\text { Autonomy from the political will of } \\
\text { the regime }\end{array}$ \\
\hline Relationship with citizens & Administration & Citizen charter/ service first \\
\hline
\end{tabular}

Notwithstanding above, public sector reforms have to be weaved around six key factors: (a) pace, coherence and sequencing of the reforms; (b) consensus leadership and political support to inspire and sustain the reforms and to mitigate resistance; (c) communication strategy to communicate reforms to a larger audience; (d) design adaptation requiring ability of the change management teams at all levels to adapt and real time adjustment to deal with emerging challenges; (e) legal/strategic framework as anchors for providing legal cover to reforms, wherever required; and (f) linking the reform framework to deliverables and performance. Prudently crafted reforms having strong political support and are enforced by competent and motivated leadership and staff are likely to succeed. Compromises and weaknesses in any of these domains will never have desired impact. Incidentally, most public sector and civil service reforms till-date suffered from compromises and weaknesses in all these domains. Suggestions on some of key elements of CSR are discussed below.

\subsection{All-Pakistan Service}

Civil Service of Pakistan was constituted following an agreement between the Governor General and the Governors of the provinces of the Provinces and Civil Service of Pakistan (Composition and Cadre) Rules, 1954 were notified. Article 179 of the 1956 Constitution recognized an All-Pakistan Service, a service common to the Federation and the provinces. Article 240 of 1973 Constitution reiterated the provisions for an All-Pakistan Service and 1954 Rule have been protected under Article 268. So, quite often the critique on All-Pakistan Service is misplaced.

\subsection{Federal Secretary's Appointment}

Recently, the Task Force recommended selection of a Federal Secretary through a highpowered Committee for a tenure of three years. Nevertheless, addition of three Ministers in the Committee for selection of a Federal Secretary will politicize the bureaucracy further. Appointing the Secretary on probation for six months initially will leave him at the mercy of the Minister-in-Charge and will lead to political compromises which is expected to end up politicizing the bureaucracy more than ever. Nowhere in the world in parliamentary democracies, a permanent secretary or a federal secretary is appointed on probation and there is no such provision in the Civil Servant Act or Rules.

\subsection{Revamping the Public Service Commissions}


Recruitment into Civil Service pre-supposes an apparatus manned by personnel of high intellect, quality, integrity and leadership. While Public Service Commission's retain constitutional protection and mandate in all SAARC ${ }^{15}$ Countries with complete independence, it has been left to the mercy of legislature in Pakistan since 1973. Its autonomy has been further diluted by down-grading it to an Attached Department of the Establishment Division. All Commissions (Federal and Provincial) in Pakistan are relegated to centers of political patronage. It is important that all the Commissions must be either provided constitutional protection and mandate like other SAARC countries or restore its statutory independence as held by the Supreme Court of Pakistan in its judgement of March 16, 2015 "We, however, note that the Federal Public Service Commission is an independent statutory body which also derives validity from Article 242 of the Constitution". Secondly, the number of members may be increased to 15 because of ever increasing load. Thirdly, the law must stipulate qualifications for appointment of members and chairman rather than leaving it to the discretion of the Government. Fourthly, the Government may notify revised FPSC Act, FPSC Rules and FPSC Conduct of Business Rules vetted by the Ministry of Law in 2015 to accomplish its autonomy. Fifthly, Commissions also requires improvement in technology, staff's quality and its examination system;

\subsection{Human Resource Management (HRM) and Plan}

Human Resource Plan and Management System is missing at all levels of the Government. Staff allocation is not aligned to assigned mandate or goals and programs reflected in the Rules of Business or Medium-Term Budgetary Framework. Absence of key elements of HRM, such as, job description or performance indicators creates inefficiency and opaqueness in personnel management. Absence of HR planning results in overstaffing and difficulty in promotion or transfer. Purpose specific cells or wings sanctioned continue infinitely irrespective of their requirement resulting into adjustment of favourites against higher-scale positions and wasteful expenditure. HRM Plan must lead to rationalize staffing of each Ministry to determine its optimal size corresponding to assigned functions, preparing job description for each staff position, and develop performance indicators and contracts for desk officer to senior management to determine skills needs and effective performance evaluation. Once it is done, the Government must segregate all positions at federal level into: (i) Competitive hiring position; (ii) Senior Executive Service positions; (iii) Contract Hiring positions; and (d) Support staff positions. Cross-merger of such positions or manpower must be discouraged to avoid tensions. The Government must also determine cadre strength of each service and transparent sharing of position in BPS-17 to 22 and notify rules for induction of officers of other services into the Secretariat service. It also needs to design and develop career development path for officers in BPS-17 to 21 to groom the talent and each Ministry must notify delegation of authority.

${ }^{15}$ South Asian Association of Regional Cooperation 


\subsection{Merit Based Hiring in Civil Service}

Induction into civil service is not just about filling current vacancies, as is generally perceived, but making a continuous, long-term investment in attracting a persistent flow of highly qualified and skilled men and women capable of accomplishing the assigned mission now and in the future. It is proposed that for the Competitive Examination: (a) all aspirants must qualify Civil Service Aptitude Test-I and II; (b) qualified candidates (1:20 ratio for each vacancy) may undertake Written Examination (i) four compulsory subjects and (ii) cluster-based examination in at least four optional subjects; (c) divide the current occupations into four clusters: (i) Administrative Services-Pakistan Administrative Service, Police Services of Pakistan, and Secretariat Service; (ii) Pakistan Foreign Service and Commerce and Trade Group; (iii) Financial Management Services-Inland Revenue Service, Pakistan Custom Service, Pakistan Audit and Accounts Service; and (iv) General Management Services-Information Group, Military and Land Cantonments, Postal Service Group, Railways Group; (d) psychometry test of qualified candidates; and (e) viva voce. Induction of armed forces officers as well as Provincial Management Services against their quota into specified federal services must be governed through competitive process including written examination and viva voce. For others, the Commission and the Government must review and refurbish the induction system as it is quite discretionary now. Gradually, the whole system of examination may be reformed to align with modern practices in developed countries, such as, United Kingdom, Australia, Canada, USA, etc.

\subsection{Training}

Initial and adaptational training is of paramount importance in a career system. There is a need to redefine the philosophy, format, and duration of various trainings as well as restructuring and strengthening training institutions in Pakistan. Training must be geared towards not only improving knowledge, skills and abilities but also attitudinal changes, inculcating positive values and engendering an excellent work culture. The development of expertise and specialization, so critical to deal with $21^{\text {st }}$ Century challenges, can be made possible through advanced study in specified fields required in the Government. Mode of trainings may be changed from general lecturing by retired civil servants to domain related case studies, syndicate discussions, focused group policy papers, off-the-tray exercises, whole-of-government and inter-agency coordination, E-governance, negotiation skills, conflict resolution, public speech, and international best practices.

\subsection{Performance Appraisal System}

Performance appraisal system in Pakistan remains a tool of control rather than innovation and development. Annual Performance Evaluation Report (PER) because of its implications for promotion, career prospects and premature retirement has significant consequences. However, in Pakistan, it has no no quantifiable targets and 
objective standards as Garvin (1993) puts it that "if you cannot measure it, you cannot manage it. Secondly, postings and transfers as well as salary progression are not linked to it, therefore, it is of least consequences except when it comes to promotion of a civil servant. Congeniality, agreeableness, amiability and understanding with boss or higher up or the one who will fill the PER greatly determine the overall scoring and performance being evaluated.

The system continues to be susceptible to political and bureaucratic manipulations as observed by Justice Dorab Patel, Chairman, 1991 Service Reform Commission that "ACRs have long ceased to give a true picture of the performance of a civil servant because reporting officers did not dare to make adverse entries in the ACRs of their subordinates for fear of harassment. Therefore, all attempts to improve the method of promotion will have little effect until our values change.... the most important qualities required in a civil service are integrity and character, and as the assessment of these qualities by another officer can only be subjective..., ACR system has broken down because officers are reluctant to pass adverse remarks against their subordinates." Even Presidents Jimmy Carter, Ronald Reagan, George H.W.Bush, Bill Clinton, and George W. Bush in US attempted to implement ratings systems that would truly reflect differences in performance and skill. While their efforts occasionally resulted in shortlived improvement, the U.S. Government Accountability Office continues to report that overly high-performance ratings plague the government. ${ }^{16}$

A fair, efficient, and effective performance appraisal system is the lynchpin of civil service reform. Three performance measurement models are in vogue: (a) balanced scorecard model developed by Kaplan (2010) and ISOREITA (2008), establishing link between financial measures with outcome measures; (b) SMART model of Cross and Lynch (1992) ${ }^{17}$ linking performance measures at each level of organizational hierarchy; and (c) performance Prism Model of Neely et al (2001) ${ }^{18}$ incorporating the idea of inclusiveness of stakeholders in performance management. Various techniques have been developed over time including ranking method, graphic rating scale, critical incidence, narrative essay, management by objective, human resource accounting, 360 degree and 720 degree to assess performance.

It is important that the government may create a reliable and comprehensive system for work performance; develop key indicators for measuring performance at all levels, groups and classification of public service; and objective assessment against those measurable performance indicators. The system must encompass a determination of annual work targets aligned with medium-term budgetary framework, a mid-year

\footnotetext{
${ }^{16}$ Donald J. Devine, "Reforming the Federal Bureaucracy: Challenge and Opportunity", The Heritage Foundation, Dec. 10, 2018.

${ }^{17}$ K. F. Cross (1992). For good measure. CMA Magazine, Vol. 66 No. 3, pp.20-24.

${ }^{18}$ Neely, A., Adams, C., \& Crowe, P. (2001). The performance prism in practice. Measuring Business Excellence, 5(2), 6-12.
} 
review of work targets, an open process of performance appraisal for appraising personnel functions including training, placement, promotion and salary progression as well as work planning, supervision, motivation, counselling, and development. Professional skills of officers at senior management level must be assessed to three functional areas: leadership, professional skills, domain areas specialization, policy formulation, and programs implementation.

\subsection{Promotion}

Civil service promotion is increasingly hinging on patronage, political dimension, and regional and gender considerations. Such political biases are more pronounced in countries with diverse ethnicity and political polarization, like us. Promotion to each next higher scale be linked with: PER record upto the year immediately preceding the DPC or CSB, required length of service and a minimum of service in each of the lower scales/rank, successful completion of mandatory training and ranking achieved as well as degree course in in one of the prescribed specialized fields, updated filing of Income Tax Return and Declaration of Assets duly reconciled, variety of experience for promotion to BPS-19 and above, compliance to rotation, pending Inquiries and end outcome thereof, functional ability, leadership, and potential for higher management, and accomplishments. Services may be dispensed with after two consecutive supersession and civil Servant must be provided grounds for Supersession with necessary legal amendment.

\subsection{Compensation}

The inability of governments to retain qualified staff has an impact on their capacity to manage the formulation and implementation of development policies and programmes (McCourt, 2006). Some countries attempted to address this problem through creating 'special' projects with parallel structures within government ministries (Sulemane and Kayizzi-Mugerwa, 2003). Staff in these projects are pampered with a variety of allowances and command better pay (Therkildsen, 2008). The challenge, however, is that this approach creates temporary islands of excellence that do not strengthen the capacity of the government to deliver in future (Blair, 2010). Moreover, they bring coordination and serious principal-agent problems to the fore - issues that pay and rationalization reforms ostensibly set out to address in the first place. Greckhamer (2011) defined compensation as all forms of financial returns and tangible services and benefits that employees receive as part of an employment relationship.

The objectives of equitable compensation are: attracting high quality talent, retain and reward talent, inducing performance and accountability, and total cost is fiscally sustainable. There are different theories to determine compensation for the executives: (i) cognitive theory based on employees' perception of their working environment and affects motivation; (ii) equity theory which deals individuals' perception of the ratio of inputs (work performance) and outcomes (reward) in relation to people who perform 
the same job; (iii) human capital theory which argues that accumulation of skills and knowledge gained through education and experience is a key element of compensation; (iv) managerial power theory, i.e. perceptions created that managers act in their own interests at the expense of the interest of shareholders; (v) structural theory in which compensation is a direct function of the number of organizational levels below top management; and (vi) contingency/institutional theory where external and internal factors influence compensation decisions. A combination of cognitive, human capital, equity, structural and institutional theories determine the compensation.

Today, major reform challenges the government is facing is to enhance capacity of ministries within reasonable personnel cost. It is important that the Government may move out of "one-size-fits-all" notion introduced in 1973 and develop separate wage scales by profession, by individual sector and ministries, skills and qualification, and performance and index it with cost of living. Perks may be gradually monetized. However, it will require a fiscal framework for financial sustainability combined with moving from pay-as-you-go pension system to contributory pension. Thus, mere compensation reform will yield the desired result. It must be combined with reforming the archaic pension system in Pakistan.

\subsection{Accountability}

Figure 7. Accountability

"Too much centralization undermines the flexibility needed to serve government's greatly varied purposes. Too much decentralization undermines its embrace of core principles," 19 as referred to above. Therefore, a system of accountability focused on results is the theme for civil/public service in $21^{\text {st }}$ Century (see Figure 7). There is a need to establish standing discipline authority/committees for expeditious disposal of inquiries under Efficiency

and Discipline Rules against civil servants and revamping the Services Tribunal to strengthen internal accountability. It is also

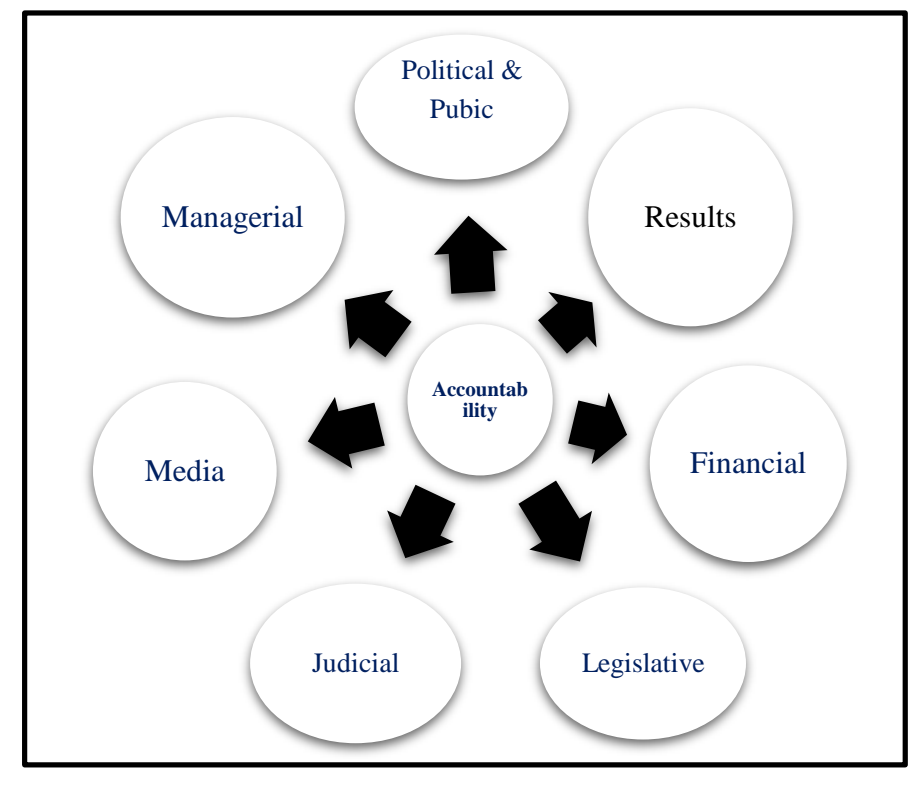
proposed to decentralize the system of internal accountability by delegating powers to the Administrative Secretaries for disciplinary action against officials up to Desk (Section) Officers. It is equally important to establish statutory whistle blower system with full legal protection to the whistle blower to make the system more transparent and corruption free.

\footnotetext{
${ }^{19}$ US National Academy of Public Administration, "No Time to Wait: Building a Public Service for the 21st Century", July 2017.
} 


\section{Conclusion}

There are two options available for civil service/public service reforms: first, a radical restructuring of the existing bureaucratic order. Secondly, a piece-meal but holistic reform of the existing bureaucratic institutions with a clear time-frame. I tend to favour the later approach as the country has experienced appalling results of "Big-Bang Approach" to restructuring of these institutions in 2001 and 2010. However, the gradual approach must be well integrated, and time bound in all tiers of the Government: (Federal, Provincial, and Local) rather openended exercise with no impacting result. Specific reforms needed include functional rationalization, human resource induction, training and management, pay reform, and public financial management. Likewise, reforming the internal and external accountability including the anti-corruption institutions and disciplinary regime may also be part of this reform

The current constitutional scheme infers decentralization, co-production, collaborative and participative governance. Statutory autonomy pre-supposes autonomous institutions and agencies and pressure free decision-making. It must be known that political resistance to rationality, restraint, embeddedness and autonomy leads to patrimonialism, corruption, oligarchy, and capture which weakens state's capacity. Acknowledging that the political leadership can only deliver on its promises through public servants, it is in the interest of the Government as well as interest of the nation to have a professional and capable Civil Service that continues to be strengthened and developed to deal with the challenges of 21st Century and deliver services to the people. For this to happen, the Government need to cultivate an environment where every Civil Servant must: (i) realize that they will not and cannot let the public down; (ii) acknowledge that they cannot betray the trust of the public; (iii) learn from the world, innovate and implement the best; (iv) keep grooming the next generation to meet the higher expectations of the public; and (v) fair and equitable compensation package. The key values underpinning the Civil Service for producing such civil servants must include: leadership, integrity, innovation, ability for strategic thinking and planning, capacity to formulate public policies to respond to emerging challenges and their implementation, competence to take decisions and continual learning with constitutional security of tenure and job.

Recognizing what Michel Foucault said that "Power is everywhere" and "comes from everywhere," so in this sense is neither an agency nor a structure. Instead it is a kind of 'metapower' or 'regime of truth' that pervades society, and which is in constant flux and negotiation." 


\section{Bibliography}

1. Bezes, Philippe, Jeannot, Gilles. "The Development and Current Features of the French Civil Service System", Van der Meer Frits, Civil Service Systems in Western Europe, Cheltenham, Edward Elgar, p. 185-215, 2011.

2. Biesen, Guy Van-Biesen, (2006)., "Overview Of Civil Service Selection Procedures In Eu Context”, European Personnel Selection Office (EPSO), Belgium, March 2006

3. Bukenya, Badru, and Yanguas, "Building State Capacity for Inclusive Development: The Politics of Public Sector Reform", Working Paper No. 25, Effective States and Inclusive Development Research Centre (ESID), The University of Manchester, UK.

4. Burns, John P., "Civil Service Reform in China", OECD Journal on Budgeting Volume 7 - No. 1 - Issn 1608-7143, 2007

5. Cho,Prof. Chang-hyun, "Professional Civil Service of Korean Government", Republic of Korea Civil Service Commission http://www.csc.go.kr/ 11/2003.

6. Congressional Budget Office, "Comparing the Compensation of Federal and PrivateSector Employees, 2011 to 2015, www.cbo.gov/publication/52637

7. Cross, K.F., (1992). For good measure. CMA Magazine, Vol. 66 No. 3, pp.20-24.

8. Devine, Donald J., "Reforming the Federal Bureaucracy: Challenge and Opportunity", The Heritage Foundation, Dec. 10, 2018.

9. Edmans, Alex, Gabaix, Xavier, and Jenter, Dirk., "Executive Compensation: A Modern Primer", ECGI Working Paper Series in Finance, http://ssrn.com/abstract_id=2576707

10. Farazmand, Ali (ed.), Administrative Reform in Developing Nations, 2002

11. Garvin, David A., "Building a Learning Organization", Harvard Business Review, July-August 1993 Issue.

12. Government of Pakistan, National Commission of Government Reforms Report, 2008

13. Greckhamer, Thomas, Cross-cultural Differences in Compensation Level and Inequality across Occupations: A Set-theoretic Analysis, February 2011, Organization Studies 32(1):85-115, DOI:10.1177/0170840610380806

14. Grimshaw, Damian, Marino, Stefania, and Rubery, Jill, "Public sector pay and procurement in the UK", EWERC, Manchester Business School, University of Manchester, November 2012.

15. Haddon, Catherine, "Reforming the Civil Service", Institute of Government, July 2012, https://www.instituteforgovernment.org.uk/sites/default/files/publications/CMPS\%20i n\%20template\%20FINAL.pdf 
16. Hanif, Ayesha, Jabeen, Nasira, and Jadoon, Zafar Iqbal, "Performance Management in Public Sector: A Case of Civil Service in Pakistan", South Asian Studies Vol. 31, No. 1, January - June 2016, pp.99-116

17. International Monetary Fund, (June 2016). "Case Studies On Managing Government Compensation And Employment-Institutions, Policies, And Reform Challenges”, http://www.imf.org/external/pp/ppindex.aspx

18. IŠORAITE், Margarita, “The Balanced Scorecard Method: From Theory To Practice", Intellectual Economics 2008, No. 1(3), p. 18-28.

19. Kaplan, Robert S., "Conceptual Foundations of the Balanced Scorecard", Harvard Business School, Working Paper 10-074, 2010

20. Lee, Eun-Suk, and Kim, Seongsu, "Best Practices and Performance-Based HR System in Korea", Seoul Journal of Business, Volume 12, Number 1 (June 2006)

21. Lukashenko, Olga, Vlajković, Vladimir, and Stojanović, Jasna, Towards Effective Public Administration: Methodology For Functional Analysis, 2009.

22. Manning, Nick, and Parison, Neil, "Determining the Structure and Functions of Government Program and Functional Reviews", The World Bank, Moscow, October 2004.

23. Muhyiddin, "Corruption and Development: A Cross Country Analysis", Journal of Development Planning (Edition: number 03/XII April-June 2007).

24. Neely, A., Adams, C., \& Crowe, P., (2001). The performance prism in practice. Measuring Business Excellence, 5(2), 6-12.

25. Nwasike, Joan, and Maina, Dunstan (eds.), Key Principles for Public Sector Reforms, The Commonwealth, 2018

26. O'reilly, Dermot, and Reed, Mike, "Leaderism': An Evolution Of Managerialism In Uk Public Service Reform", Public Administration Vol. 88, No. 4, 2010 (960-978), Blackwell Publishing Ltd, 9600 Garsington Road, Oxford OX4 2DQ, UK and 350 Main Street, Malden, MA 02148, USA.

27. Pollitt, Christopher, Bouckaert, Geert, Public Management Reform, Fourth Edition, 2017

28. Poocharoen, Ora-orn, and Mai, Chiant, "Meritocracy in Asia Pacific Status, Issues, and Challenges", Article in Review of Public Personnel Administration · June 2013, https://www.researchgate.net/publication/258183551 
29. Rana, Shan-Aman, "Discretion in a Bureaucracy-Evidence from Pakistan", Policy Brief 37303, International Growth Center, June 2019.

30. Stiglitz, Joseph E., "Markets, States And Institutions", Roosevelt Institute Working Paper, June 2017.

31. Sulemane, Jose' A., and Kayizzi-Mugerwa, Steve, Reforming Africa's Institutions Ownership, Incentives, and Capabilities, United Nations University WIDER, 2003

32. Therkildsen, Ole, Public Sector Reforms and the Development of Productive Capacities in LDCs, Background Paper No. 1, UNCTAD, March 2008, https://www.diis.dk/files/media/publications/import/extra/ldcr2009_therkildsen_en.pd $\underline{f}$

33. Ul-Haq, Nadeem, (2007). "Why Civil Service Reforms do not Work", SSRN Electronic Journal, February 2007.

34. Ulleberg, Inger, "Incentive Structure as a Capacity Development Strategy in Public Service Delivery”, UNESCO, 2009

35. US National Academy of Public Administration, "No Time to Wait: Building a Public Service for the 21st Century", July 2017.

36. Wild, Leni, Chambers, Victoria, King, Maia, and Harris, Dan, "Common Constraints And Incentive Problems In Service Delivery", Working Paper 351, Overseas Development Institute, www.odi.org.uk/

37. Wilkins, John, "Strategic leadership of public sector", Commonwealth Governance Handbook, 2013-14.

38. World Bank, Governance Indicators 2018.

39. World Bank, "Poland: Reforming Government Pay Setting Practices", June 11, 2013. 